\title{
Histopathological characterization of the reproductive organs of heifers experimentally infected with Campylobacter fetus venerealis
}

\author{
Caracterización histopatológica de los órganos reproductivos de vaquillonas experimentalmente \\ infectadas con Campylobacter fetus venerealis
}

Caracterização histopatológica em órgãos reprodutores de novilhas infetadas no modo experimental com

Campylobacter fetus venerealis

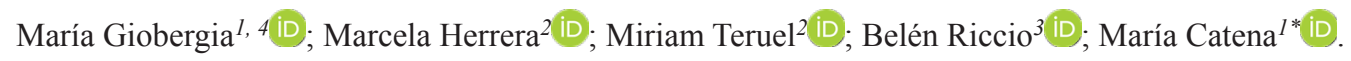

\begin{abstract}
${ }^{1}$ Área de Enfermedades Infecciosas, Departamento SAMP-CIVETAN, Facultad de Ciencias Veterinarias, Universidad Nacional del Centro de la Provincia de Buenos Aires, UNCPBA, Tandil, Buenos Aires, Argentina.

${ }^{2}$ Área de Ciencias Morfológicas, Departamento Ciencias Biológicas, Facultad de Ciencias Veterinarias, Universidad Nacional del Centro de la Provincia de Buenos Aires, UNCPBA, Tandil, Buenos Aires, Argentina.

${ }^{3}$ Área de Patología, FISFARVET-CIVETAN, Facultad de Ciencias Veterinarias, Universidad Nacional del Centro de la Provincia de Buenos Aires, UNCPBA, Tandil, Buenos Aires, Argentina.

${ }^{4}$ Beca Consejo Interuniversitario Nacional, Argentina.
\end{abstract}

To cite this article:

Giobergia M, Herrera M, Teruel M, Riccio B, Catena M. Histopathologic characterization of the reproductive organs of heifers experimentally infected with Campylobacter fetus venerealis. Rev Colomb Cienc Pecu 2020; 33(3): 149-158. DOI: https://doi.org/10.17533/udea.rccp.v33n1a05

\begin{abstract}
Background: Bovine campylobacteriosis is a venereal disease due to infection with Campylobacter fetus venerealis. It causes mainly reproductive failures that lead to considerable economic losses. Objective: To perform a histopathological description of the mucosa from reproductive organs of heifers experimentally infected with Campylobacter fetus venerealis. Methods: Twelve 15-18-months-old Aberdeen Angus heifers were treated for estrous synchronization and exposed to natural breeding. They were then randomly divided into two groups: group $\mathrm{A}(\mathrm{n}=9)$ was inoculated with $\mathrm{C}$. fetus venerealis; group B ( $n=3$, control) was inoculated with a placebo. Ultrasonography was performed at days 29, 38, and 42 post-breeding, and plasmatic progesterone levels were quantified using ELISA to confirm pregnancies. Animals in group A with plasma progesterone levels below $1 \mathrm{ng} / \mathrm{mL}$ and/or diagnosed as non-pregnant were further divided into three subgroups: A1 ( $\mathrm{n}=4$ ), euthanized at day 30 post-breeding; A2 ( $=3$ ), euthanized at day 40 post-breeding and A3 ( $n=2)$, euthanized at day 55 postbreeding. Heifers from group B, all diagnosed as pregnant, were euthanized each at day 30, 40, and 55 days post-breeding as well. Histological sections from every group were taken from oviducts, uterus, and vagina. Results: Lymphocytic inflammation was the most common lesion in all infected heifers. Trophoblast cells were found in the non-pregnant heifers euthanized at days 40, and 55 post-breeding. The inflammatory process with the presence of lymphoid cells probably altered the balance in
\end{abstract}

Received: September 5, 2018; accepted: August 20, 2019

*Corresponding author. Buenos Aires, Argentina. Tel.: 54924944385850, int 3350. E-mail: mcatena@vet.unicen.edu.ar

(c) (1) (ㅇ)

BY NC SA This work is licensed under a Creative Commons Attribution-NonCommercial-ShareAlike 4.0 International License. 
the activity of maternal lymphoid cells, as well as gene expression of the trophoblast, finally affecting the embryo survival. Conclusion: This work contributes to the understanding of the histopathological process involved in post-mating infection of Campylobacter fetus bovine.

Keywords: Campylobacter fetus venerealis; cattle; heifers; histopathology; lymphocytic inflammation; oviduct; postmating infection; uterus; vagina; venereal disease.

\section{Resumen}

Antecedentes: La campilobacteriosis bovina es una enfermedad venérea causada por el Campylobacter fetus venerealis, que produce principalmente fallas reproductivas ocasionando grandes pérdidas económicas. Objetivo: Describir las características histopatológicas de la mucosa de órganos reproductores de vaquillonas infectadas experimentalmente con Campylobacter fetus venerealis. Métodos: Doce vaquillonas Aberdeen Angus (15 a 18 meses de edad) con celo sincronizado, recibieron servicio natural, e inmediatamente se dividieron aleatoriamente en dos grupos: A ( $\mathrm{n}=9)$, inoculadas con Campylobacter fetus venerealis; $\mathrm{B}(\mathrm{n}=3$; control), inoculadas con placebo. El diagnóstico de preñez se realizó por ultrasonografía a los 29,38 y 42 días post-servicio; los niveles plasmáticos de progesterona fueron determinados por ELISA. Las vaquillonas del grupo A con niveles de progesterona plasmáticos menores a $1 \mathrm{ng} / \mathrm{mL}$ y/o diagnosticadas no preñadas, fueron consideradas para eutanasia y divididas en tres subgrupos: A1-eutanasia día $30(n=4)$; A2-día $40(n=3)$; y A3-día $55(n=2)$ post-servicio. Las vaquillonas del grupo B, diagnosticadas preñadas, fueron eutanasiadas a los 30, 40 y 55 días. Se tomaron muestras de oviductos, útero y vagina. Resultados: Se observó inflamación linfocitaria en la totalidad de muestras del grupo A. Células trofoblásticas fueron encontradas en muestras correspondientes a los grupos A2 y A3. Probablemente, el proceso inflamatorio alteró el equilibrio de las células linfoides maternas y la expresión génica del trofoblasto, afectando la supervivencia embrionaria. Conclusión: Este trabajo contribuye a la comprensión del proceso histopatológico involucrado en la infección poscoital por Campylobacter fetus bovino.

Palabras clave: Campylobacter fetus venerealis; enfermedad venérea; ganado; histopatología; infección post-servicio; inflamación linfocitaria; oviducto; útero; vagina; vaquillona.

\section{Resumo}

Antecedentes: A campilobacteriose bovina é uma doença venérea originada pelo Campylobacter fetus venerealis, quem produz principalmente falha reprodutiva e porém grandes perdas económicas. Objetivo: Descrever as características histopatológicas da mucosa dos órgãos reprodutores de novilhas infetadas no modo experimental com Campylobacter fetus venerealis. Métodos: Doze novilhas Aberdeen Angus de 15 até 18 meses com cio sincronizado, receberam serviço natural. Logo após, foram aleatóreamente separados em grupos: $\mathrm{A}(\mathrm{n}=9)$ inoculados com Campylobacter fetus venerealis e grupo $\mathrm{B}(\mathrm{n}=3$; controle) inoculadas com um placebo. O diagnóstico da gestação foi realizado por ultrasom nos dias 29,38 y 42 pós-serviço. Os níveis plasmáticos da progesterona foram determinados por ELISA. As novilhas do grupo A, com níveis plasmáticos de progesterona menores a $1 \mathrm{ng} / \mathrm{mL}$ e/ou diagnosticadas não grávidas, foram consideradas para eutanásia e foram divididas em três subgrupos: A1-eutanásia aos 30 dias pós- serviço $(\mathrm{n}=4)$; A2-dia $40(\mathrm{n}=3)$; A3-dia 55 (n=2). Foram realizada eutanásia ás novilhas do grupo $\mathrm{B}$ diagnosticadas prenhadas, aos 30,40 e 55 dias e a amostragem de ovidutos, útero e vagina. Resultados: A presença de inflamação linfocitária foi observada na totalidade das amostras do grupo A. Foram achadas células trofoblásticas nas amostras correspondente aos grupos A2 e A3. Provavelmente, pelo processo inflamatório tenha sido alterado o equilíbrio das células linfoides maternas, assim também como a expressão gênica do trofoblasto, afetando a supervivência embrionária. Conclusão: Este trabalho contribue á compreensão do processo histopatologico na infecção com Campylobacter fetus bovino pós-acasalamento.

Palavras-chave: Campylobacter fetus venerealis; doença venérea; gado; histopatologia; infecção pós-acasalamento; inflamação linfocitária; novilhas; ovidutos; útero; vagina. 


\section{Introduction}

Bovine genital campylobacteriosis is a venereal disease caused by Campylobacter fetus venerealis. The outcome of the disease causes reproductive failures that lead to considerable economic losses in many countries. Bulls persist infected for life, and a proportion of carrier females are the potential source of infection and incidence of the disease in the herd (Clark, 1971; Hoffer, 1981; Catena et al., 2007; Terzolo and Catena, 2010).

Campylobacter fetus is highly adapted to the mucosal surfaces (Hu and Kopecko, 2000; Kaakoush et al., 2015). Two subspecies are recognized, i.e., C. fetus venerealis and C. fetus fetus, and it is believed that the former represents a bovine clone of the latter (Gorkiewics et al., 2010). Although it is known that C. fetus venerealis colonizes the genital tract of ruminants; the underlying molecular mechanisms of infection remain largely unknown.

Most of the studies of reproductive failures are based on recognizing the etiology (ies) and contributing to the knowledge of the pathogenesis complexity in the fetal-maternal interface. Hence, certain components, like the conceptus, the maternal-conceptus relationship, and the mother in its environment, must be taken into account (Beer and Billingham, 1979; Croy et al., 2009). Within the maternal-conceptus relationship, it is important to recognize the presence of giant, binucleate trophoblast cells in the endometrium of ruminants, which appear after day 20 of gestation (Bartolomé, 2009).

The pathogenesis of campylobacteriosis is associated with the virulence factors of the bacteria and the host immune response. Pathogenic bacteria can cause damage to the host cell by mechanisms such as adhesion, invasiveness, and cytotoxin-production capacity (Casadevall and Pirofski, 2000; Brenner and Stanley, 2005). There are several reports describing the causes of embryo mortality concerning the virulence factors of $C$. fetus (Ware, 1980; Blaser and Pei, 1993; Casadevall and Pirofski, 2000). Among them, mucinase production and its microaerophilic properties might be associated with the establishment of changes in both the uterine and the oviductal environment. These changes interfere with normal preimplantation embryo, causing a delay in the implantation and the subsequent death of the embryo (Ware, 1980).

This paper describes the histopathological characteristics of the mucosa in the reproductive organs of heifers experimentally infected with C. fetus venerealis in order to contribute to the understanding of the histopathological process occurring in the post-mating infection in bovine females.

\section{Materials and Methods}

\section{Ethical Considerations}

The experiment was carried out according to the Animal Welfare Committee of the Faculty of Veterinary Sciences, National University of Central Buenos Aires Province (Academic Council Resolution 087/02, FCV, UNCPBA).

\section{Animal experiment}

Twelve 15-18-month-old Aberdeen Angus cycling heifers were used. All of them underwent an estrus synchronization protocol (prostaglandin F2 $\alpha$ (PGF2 $\alpha$ Dinoprost, Lutalyse $\left.{ }^{\circledR}\right), 25 \mathrm{mg}$, twice, with 11 days interval between doses). Twenty-four hours after the PGF2 $\alpha$ treatment finished estrus detection was conducted by performing three observations per day (at 8:00, 12:00 and 16:00), 40 min each. Once estrus was detected, each heifer was naturally bred by a bull. The breeding had been corroborated by the presence of spermatozoa with progressive motility in the cervical-vaginal mucus (CVM).

Immediately after breeding, heifers were randomly assigned to two groups: heifers in group A $(\mathrm{n}=9)$ were inoculated with $1 \mathrm{~mL}$ of $C$. fetus venerealis suspension in a semisolid medium, with a final concentration of 1 x $108 \mathrm{CFU}$, equivalent to $\mathrm{OD} 600=0.4$. The inoculation was done in the back of the vagina using a Cassou syringe and 
artificial insemination blue pods. Heifers in group $\mathrm{B}(\mathrm{n}=3$; control) were inoculated with semisolid culture medium as placebo.

Ultrasonography and determination of plasma progesterone levels were both performed for pregnancy diagnosis. Ultrasound studies were performed at 29,38 , and 42 days post-breeding with a Pie Medical 200 Vet or a Sono Vet 900 (Ekhoson S.A.) ultrasound. Blood samples from the jugular vein were taken at $0,12,21,27,29$, 31 , and 33 days post-breeding; the blood was then centrifuged within the hour of sampling to separate the plasma, which was then stored at $-20{ }^{\circ} \mathrm{C}$ until use. The concentration of progesterone was determined by an enzyme immunoassay (ELISA), with an intra-assay coefficient of variation of less than $10 \%$ for concentrations ranging from 0.4 to $25 \mathrm{ng} / \mathrm{mL}$ of progesterone and a sensitivity of $0.3 \mathrm{ng} / \mathrm{mL}$. A heifer was considered pregnant when plasma progesterone concentration was $\geq 1 \mathrm{ng} / \mathrm{mL}$ from day 21 onwards. To corroborate the presence of $C$. fetus, CVM samples were taken from heifers of group A at days $0,2,3$, and then weekly until euthanasia.

Females in group A with plasma progesterone levels below $1 \mathrm{ng} / \mathrm{mL}$ and/or diagnosed as non-pregnant by ultrasound were assigned to 3 subgroups: $\mathrm{A} 1(\mathrm{n}=4), \mathrm{A} 2(\mathrm{n}=3)$, and $\mathrm{A} 3(\mathrm{n}=2)$. Subgroup A1 was euthanized at day 30 postbreeding; A2 euthanized at day 40 post-breeding, and $\mathrm{A} 3$ euthanized at day 55 post-breeding. Heifers in subgroup A1 showed estrus 24 to 28 days post-breeding and were euthanized at day 30 ; the heifers in subgroup A2 presented estrus 38 to 40 days post-breeding and were euthanized at day 40; and heifers in subgroup A3 showed no clinical manifestation of estrus and were euthanized at day 55. The heifers in group B, which were all diagnosed as pregnant, were each euthanized at day 30 , 40 , and 55 post-breeding, similar to subgroups A1, $\mathrm{A} 2$, and $\mathrm{A} 3$, respectively.

Samples from oviducts, uterus (horns ipsilateral and contralateral to the corpus luteum [CL], uterine body, anterior cervix and posterior cervix) and vagina, were taken from each heifer, placed in cassettes and submerged in $10 \%$ buffered formalin, $\mathrm{pH}$ 7.2, for 24 hours. After that, they were set in an automatic tissue processor (Citadel Tissue Processor, Shandon), embedded in paraffin, cut into $5 \mu \mathrm{m}$-thick tissue sections (Microm Micromot HM 315) and stained with Hematoxylin-Eosin.

\section{Results}

The observations below describe the tunica mucosa of the different reproductive organs affected at first by $C$. fetus as an extracellular pathogen. Lymphocytic inflammation was the most common lesion observed.

Diffuse mononuclear infiltrate was observed in the lamina propria, blood vessels, and lumen of the oviducts of inoculated heifers. Furthermore, at days 40 , and 55 post- infection (p.i.), the oviducts showed pronounced vascularization (Figure 1A) and presence of lymphocytes and erythrocytes in the lumen (Figure 1B).
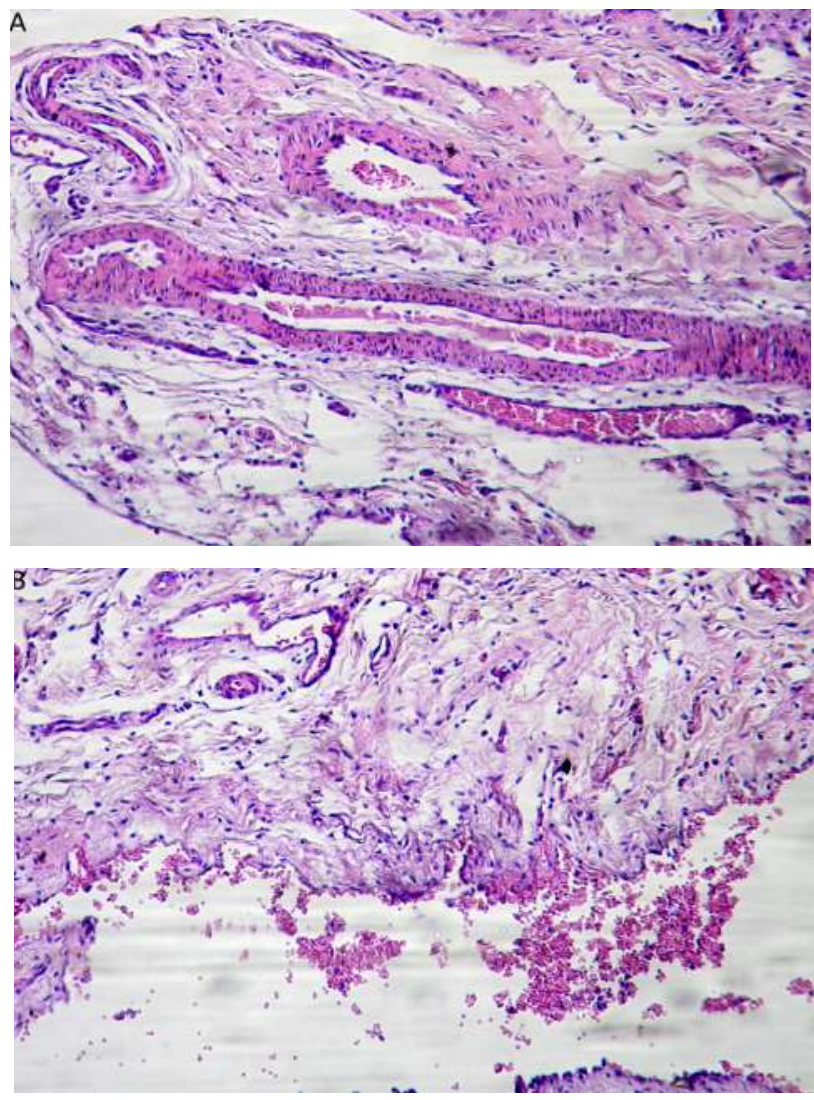

Figure 1. A. Oviduct of a heifer at day 40 p.i. showing pronounced vascularization (10X). B. Oviduct of a heifer at day 40 p.i. showing presence of lymphocytes and erythrocytes in the lumen (10X). 
At day 30 p.i. the uterine horn contralateral to the $\mathrm{CL}$ showed mononuclear and polymorphonuclear infiltrates (Figure 2A). Secretion and mononuclear infiltration were also observed in some glands.

Mononuclear infiltration in the lamina propria and gland lumen, with significant vascularization, was observed in heifers at days
40 and 55 p.i. (Figure 2B and 2C). Furthermore, lymphocyte accumulations and loss of superficial epithelium was noted at day 40 p.i. (Figure 2D). There was also histoarchitecture destruction in the most superficial endometrial glands, with mononuclear infiltration in the lumen and the periphery (Figure 2E). In addition, lymphocytes were present in the uterine horn lumen.

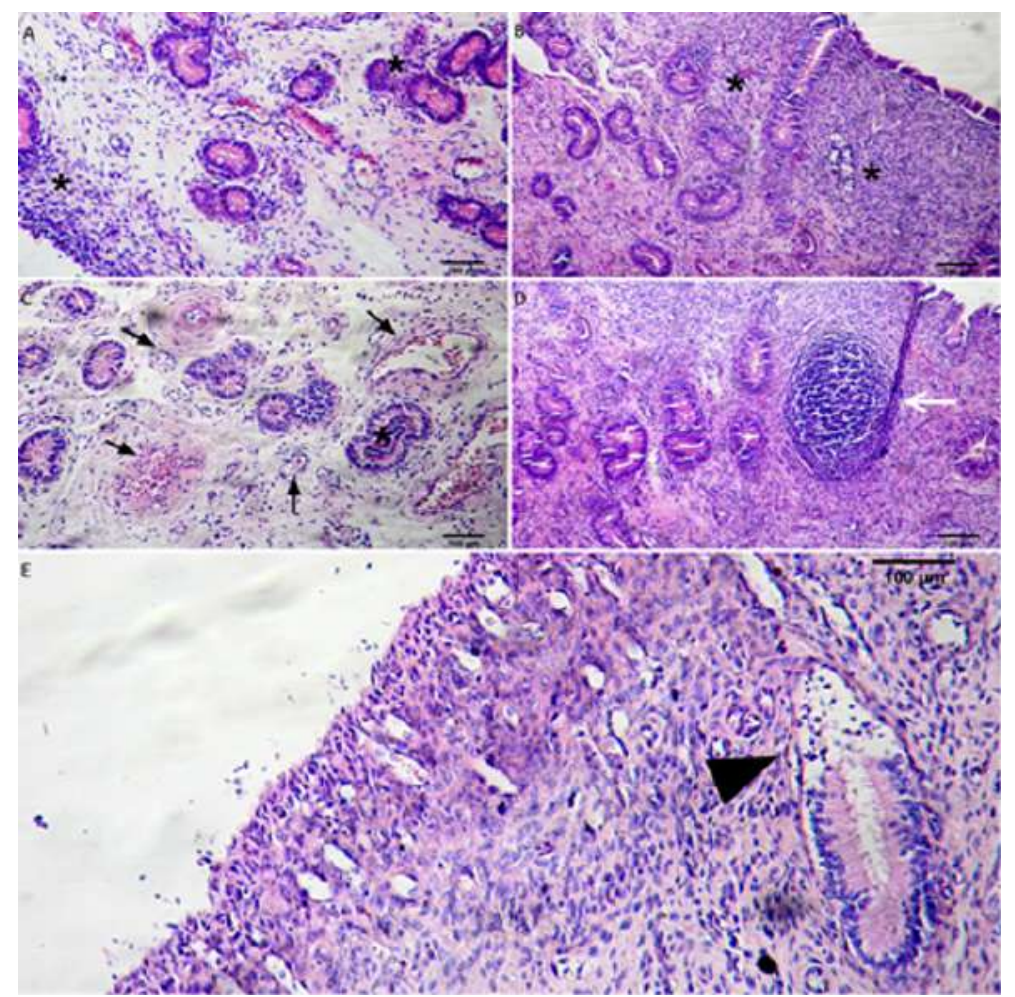

Figure 2. A. Uterine horn contralateral to CL of a heifer at day 30 p.i. showing mononuclear and polymorphonuclear infiltrates [asterisks] (10X). B. Mononuclear and polymorphonuclear infiltrates in the lamina propria [asterisks] of the uterine horn o CL of a heifer at day $40 \mathrm{p} . \mathrm{i}$. (10X). C. Glands of the uterine horn contralateral to $\mathrm{CL}$ in a heifer at day 40 p.i. showing mononuclear infiltrate in the lumen [asterisk] and marked vascularization [black arrows] (10X). D. Horn contralateral to CL of a heifer at day 40 p.i. with organized accumulation of inflammatory cells (mucosa associated lymph node) [white arrows] (10X). E. Uterine horn contralateral to CL of a heifer at day 55 p.i. showing destruction of the glandular histoarchitecture [black head arrows] (10X).

A marked inflammatory response in the histological sections of the uterine horn ipsilateral to $\mathrm{CL}$ was observed in all infected animals regardless of infection period, with the presence of mononuclear cells in blood vessels (Figure 3A), subepithelial and glandular mononuclear infiltrate (Figure 3B), and glandular dilation with nests formation (Figure 3C). Furthermore, thrombi in the blood vessels were observed in animals at days 40 and 55 p.i. (Figure 3D). Heifers euthanized at days 30 and 40 p.i. showed considerable diffuse mononuclear infiltration and presence of polymorphonuclear cells, whereas the infiltrate was mainly mononuclear in those euthanized at day 55 p.i. In these last animals, the presence of well-developed glands was characteristic as well, with epithelial hypertrophy (larger than in the horn contralateral to CL), presence of secretion, and lymphocytic infiltrate (Figure 3E).

Bi-, tri- and tetra-nucleate trophoblast cells were found in heifers euthanized at days 40 and 55 p.i. (Figure $4 \mathrm{~A}, \mathrm{~B}, \mathrm{C}$ and D). 


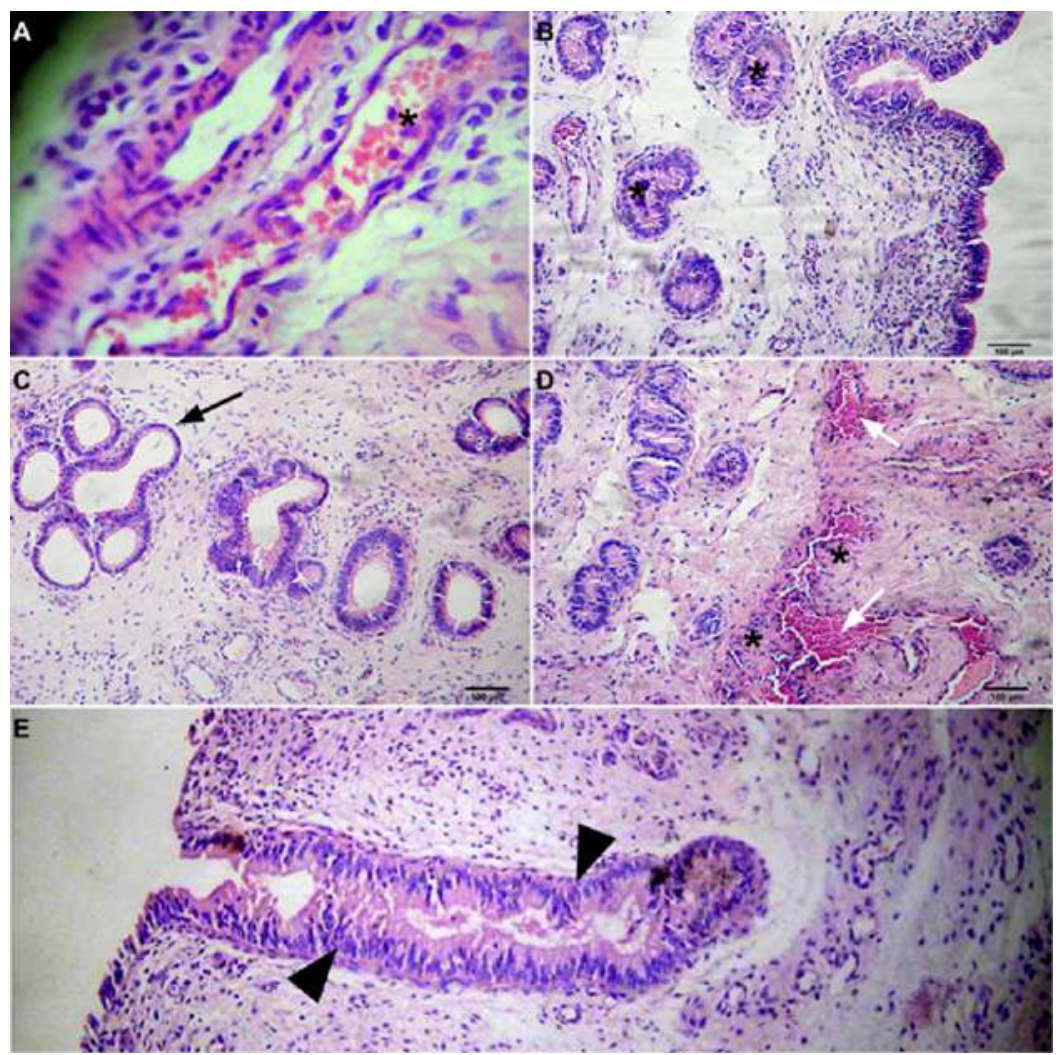

Figure 3. A. Uterine horn ipsilateral to $\mathrm{CL}$ of a heifer at day 55 p.i. intravascular mononuclear and polymorphonuclear cells can be seen [asterisk] (40X). B. Glands of the uterine horn ipsilateral to CL of a heifer at day 40 p.i. showing secretion and mononuclear infiltrate [asterisks] (10X). C. Presence of glandular dilations [black arrows] in the uterine horn ipsilateral to CL at day 30 p.i. (10X). D. Marked vascularization, presence of thrombi [white arrows] and perivascular mononuclear infiltrate [asterisks] in the uterine horn ipsilateral to CL at day 40 p.i. (10X). E. Glands of the uterine horn ipsilateral to $\mathrm{CL}$ at day 55 p.i. showing marked epithelial hypertrophy [black head arrows] and leaking of their content to the lumen of the organ (10X).

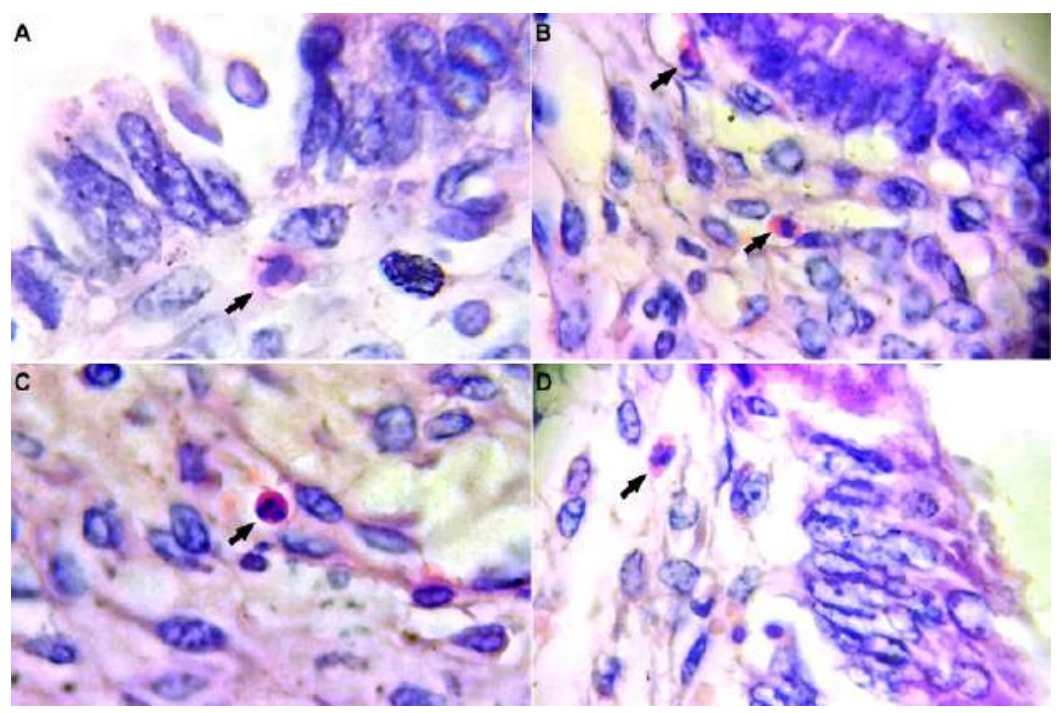

Figure 4. A. Trinucleate trophoblastic cell in the uterine horn ipsilateral to CL of a heifer at day 40 p.i. (40X). B and C. Binucleate and trinucleate trophoblastic cells in the uterine horn ipsilateral to CL of a heifer at day 55 p.i. (40X). D. Tetranucleate trophoblastic cell in the uterine horn ipsilateral to $\mathrm{CL}$ of a heifer at day 55 p.i. (40X). 
Diffuse and periglandular mononuclear infiltrate in the uterus body, with presence of polymorphonuclear cells, was observed at day 30 p.i. The endometrium showed features of a transition from estrogenic to progestational phases, according to a proliferative endometrium with presence of serrated glands, which are characteristic of a secretory endometrium (Figure 5A).

Mononuclear diffuse infiltrate was observed in the lamina propria, in the gland lumen and in the periglandular area at days 40 and 55 p.i. The endometrium revealed features of progestational phase, with increased gland development, presence of serrated glands and abundant secretion (Figure 5B). Furthermore, organized mononuclear infiltrate was also observed (Figure 5C).

The presence of abundant eosinophils in the lamina propria was noted at day 55 p.i. (Figure 5D).

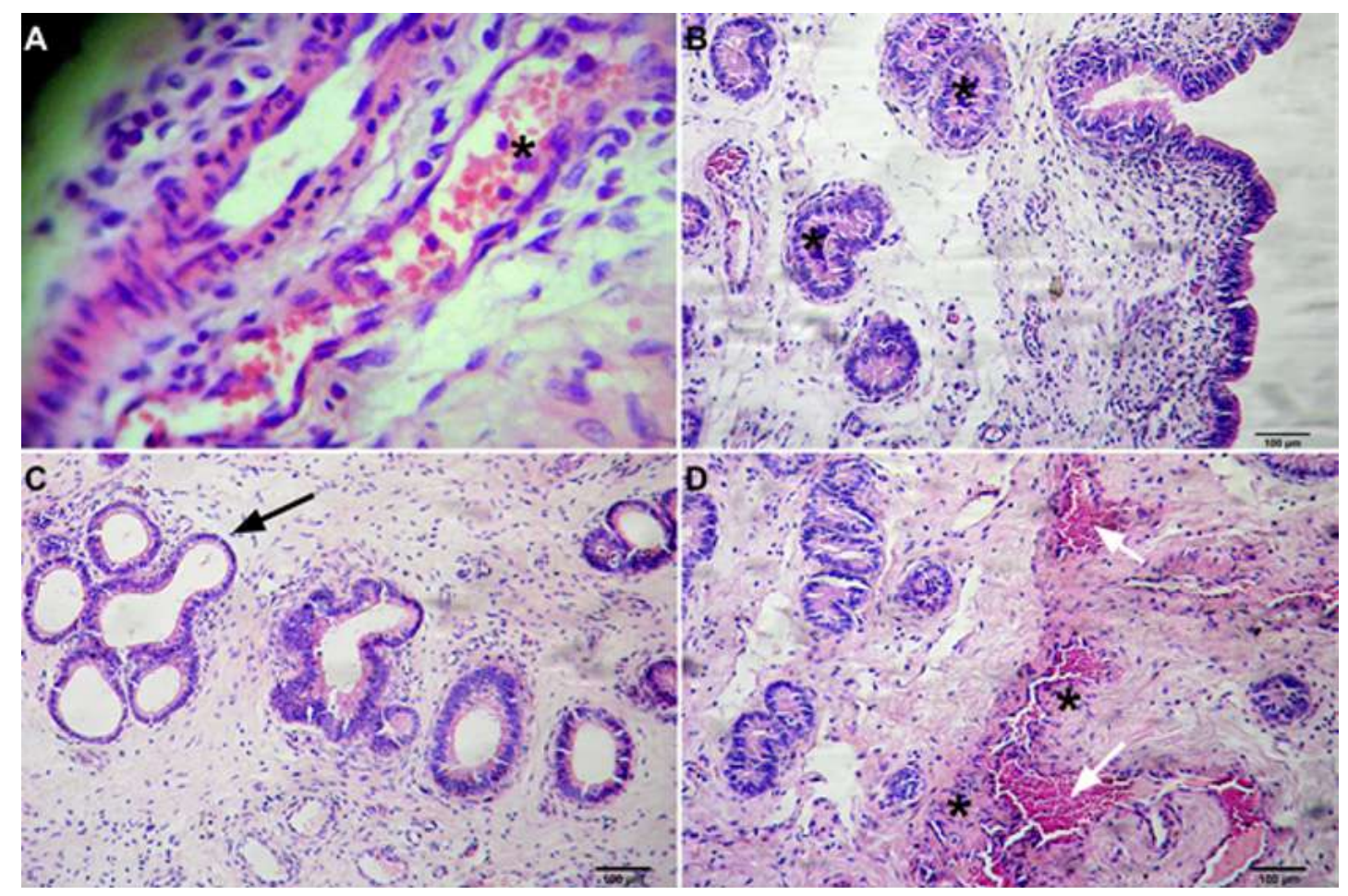

Figure 5. A. Endometrial transition between estrogenic and progestational phase in heifers at day 30 p.i., with presence of serrated glands [black arrows] $(10 \mathrm{X})$. B. Body of the uterus at day 40 p.i., showing serrated glands leaking their inflammatory content in the lumen of the organ [black arrows] $(10 \mathrm{X})$. C. Glands of the uterine body with inflammatory content and periglandular mononuclear infiltrate organized mononuclear infiltrate [white arrows] at day 40 p.i. (10X). D. Presence of eosinophils [black head arrows] in the uterine mucosa at day 55 p.i. (40X).

Diffuse mononuclear infiltrate with abundant vascularization was observed in the anterior cervix of all experimentally inoculated heifers. An abundance of mucus with mononuclear infiltrates was also present in the lumen of the organ at days 40 and 55 p.i. Furthermore, lymphocytic infiltrates were found inside the glands at day 55 p.i. (Figure 6A).
Mononuclear infiltrate was present in the posterior cervix of all heifers. Mucus with inflammatory cells in the lumen of the organ was observed at days 40 and 55 p.i. (Figure 6B).

Mild mononuclear infiltrate with significant vascularization and presence of mucus in the lumen of vagina was also noted in all histological sections (Figure 6C). 

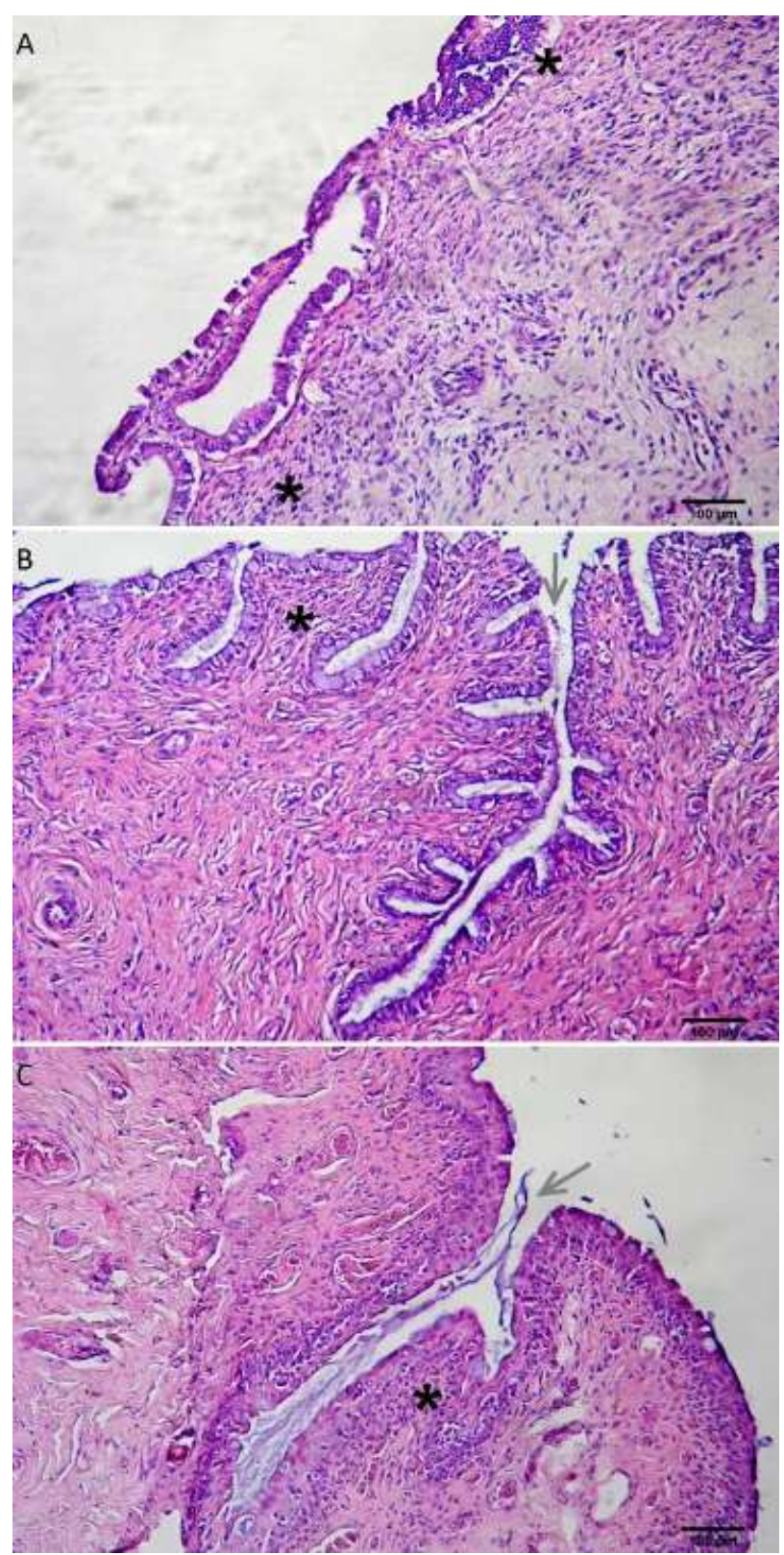

Figure 6. A. Diffuse mononuclear infiltrate in the mucosa of the anterior cervix and in the gland lumen at day 55 p.i. (10X). B. Mucosa of the posterior uterine cervix at day 40 p.i. showing slight mononuclear infiltrate and presence of mucus with inflammatory cells in the lumen of the organ (10X). C. Mild mononuclear infiltrate in vaginal mucosa at day 30 p.i. with noticeable vascularization and abundant mucus in the lumen of the organ (10X).

Normal histoarchitecture in samples from control heifers was observed, in agreement with the gestational stage. The presence of embryonic vesicle was detected by ultrasonography on day 29 (Figure 7A). Histological analysis revealed characteristics of a proliferative phase, mainly in the horn ipsilateral to the CL, with gland proliferation, which coincides with the follicular phase of the estrous cycle. This was corroborated by ovarian observation performed at necropsy. At days 40 and 55, conceptus presence was also detected (Figure 7B and 7C).
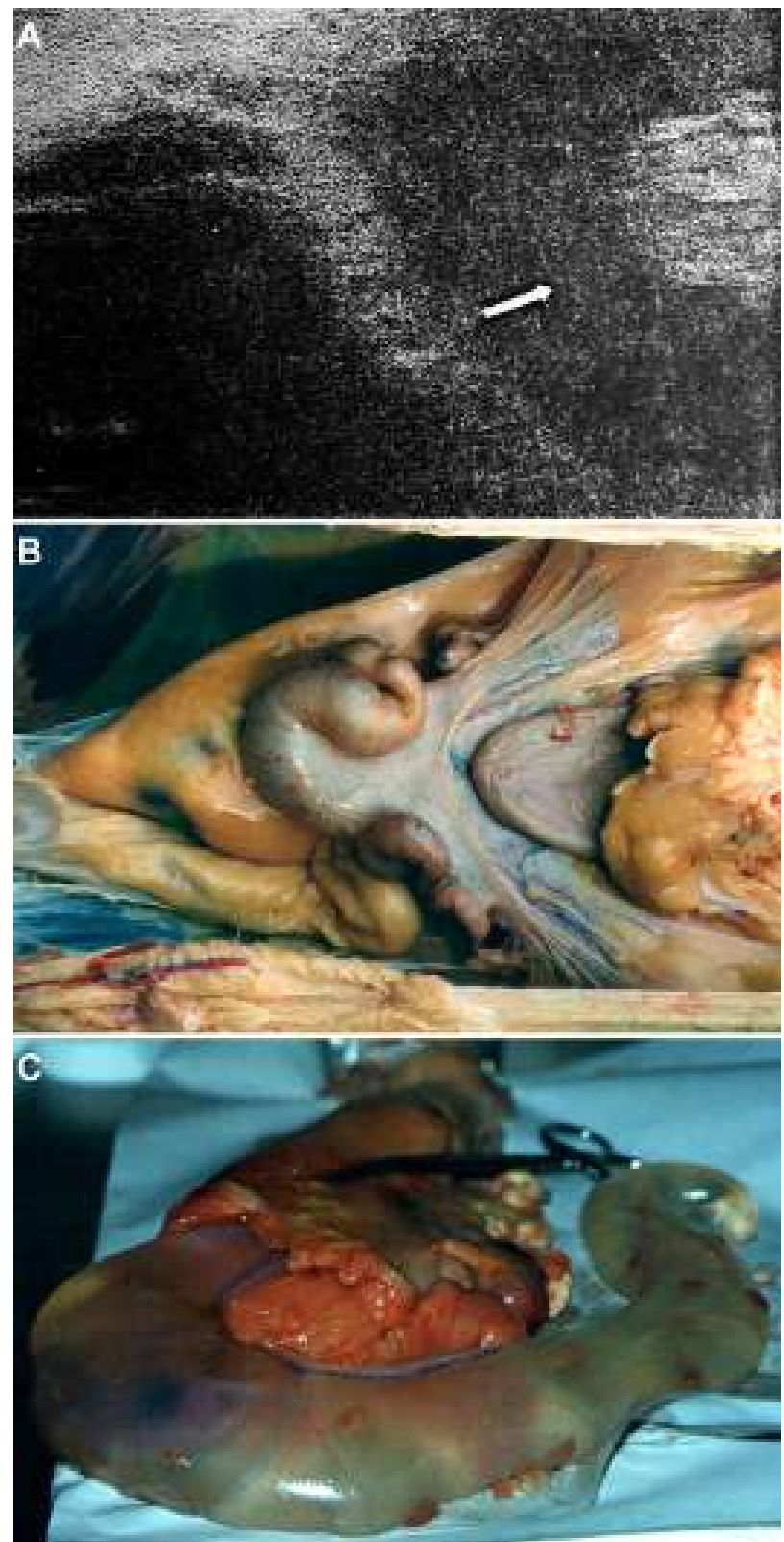

Figure 7. A. Ultrasonography corresponding to a heifer of the control group at 29 days of gestation. The arrow shows the embryonic vesicle. B. Uterine horn from a heifer of the control group at 40 days of gestation. C. Fetal and conceptus envelopes from a heifer of the control group at 55 days of gestation. 


\section{Discussion}

At present, there is little information about the histopathological changes induced by $C$. fetus venerealis infection in the early gestation stages of cattle. It is known that, depending on their virulence factors, most of the reproductive pathogens cause injuries during pregnancy, therefore altering the uterine immune function. This leads to a change in number and function of immune cells in the uterus, which potentially affects fetal survival and uterine defense mechanisms (Hansen, 2007).

The results of this study demonstrate morphological changes in the tunica mucosa of the reproductive organs associated with C. fetus pathogenesis. Histological alterations in the experimentally-infected group were more frequently observed in the uterus, probably because it prepares for gestation and is the site where pathogenesis of C. fetus develops. Differences were found between inoculated and control groups.

Infected animals presented histological changes in both uterine horns and body, corresponding to a chronic inflammatory process (Hoffer, 1981; Blaser and Pey, 1993; Catena et al., 2003; Terzolo and Catena, 2010). Histopathological changes were always more significant in the uterine horn ipsilateral to CL. This could be due to differences in progesterone concentration between the horns ipsilateral and contralateral to CL (Takahashi et al., 2016). It is likely that CL-dependent progesterone concentrations before day 50 of gestation are not high enough at the maternal-fetal interface to inhibit activation and proliferation of lymphocytes (Hansen, 2007), which would occur as a consequence of $C$. fetus presence.

The finding of binucleate cells compatible with trophoblastic cells, and tri- and tetranucleate cells indicative of interaction between trophoblastic cells and uterine epithelial cells (de Moraes Pinto et al., 2008; Bartolomé, 2009; Barbeito, 2014) in animals at days 40 and 55 p.i. is of particular significance. This, together with progesterone levels above $1 \mathrm{ng} / \mathrm{ml}$ would indicate that nidation, followed by embryo death, occurred in these females since in the same animals embryo was not detected at the time of necropsy.

The inflammatory process with presence of lymphoid cells, as observed in the uterine mucosa, probably altered the balance in the activity of maternal lymphoid cells, as well as gene expression of the trophoblast, finally affecting embryo survival.

\section{Declarations}

\section{Funding}

This study received financial support from the SECAyT-UNCPBA.

\section{Conflicts of interest}

The authors declare they have no conflicts of interest with regard to the work presented in this report.

\section{Author contributions}

Maria Catena was responsible for the experimental design and sampling; Maria Giobergia and Marcela Herrera performed histological processing of the material; María Giobergia read the samples with advice from the other authors; Maria Catena, Miriam Teruel and Marcela Herrera analyzed the histology results and wrote the manuscript. Belén Riccio collaborated with image analysis.

\section{References}

Barbeito C. Historia de las placentas y su relación con la morfología. Cs Morfol 2014; 10:1-15.

Bartolomé J. Endocrinología y fisiología de la gestación y el parto en el bovino. Taurus 2009; 11:20-28.

BeerA, Billingham R. Maternalimmunological recognition mechanism during pregnancy. Ciba Found Symp 1979; 64:293-322.

Blaser MJ, Pei Z. Pathogenesis of Campylobacter fetus Infections: Critical Role 
of High-Molecular- Weight S-Layer Proteins in Virulence. J Inf Dis 1993; 167:372-377.

Brenner DJ, Staley JT. Familia Campylobacteraceae. Género Campylobacter. In: Staley JT, Boon DR, Brenner DJ, De Vos P, Garrity GM, Goodfellow M, Krieg NR, Rainey FA, Schleifer K, editors. Bergey's Manual of Systematic Bacteriology. New York: Springer; 2005. p.1145-63.

Casadevall C, Pirofski LA. Host-pathogen interactions: basic concepts of microbial commensalism, colonization, infection, and disease. Infect Immun 2000; 68:6511-6518.

Catena M, Callejas S, Soto P, Aba M, Echevarría H, Monteavaro C, Mazzolli A. Efectos de la infección experimental con Campylobacter fetus venerealis sobre la preñez temprana en vaquillonas. In Vet 2003; 5:37-44.

Catena M, Chiapparrone L, Morán P, Pasucci $\mathrm{J}$, Echevarría H, Monteavaro C, Soto P. Adhesión de Campylobacter fetus venerealis a células vaginales y endometriales de bovinos. Rev Arg Microbiol 2007; 39:174-175.

Clark B. Review of bovine vibriosis. Aust Vet J 1971; 47:103-107. DOI: https://doi. org/10.1111/j.1751-0813.1971.tb14749.x

Croy B, Wessels J, Linton N, Tayade C. Comparison of immune cell recruitment and functionin endometrium during development of epitheliochorial (pig) and hemochorial (mouse and human) placentas. Placenta 2009;23:23-31. DOI: https://doi.org/10.1016/j.placenta.2008.09.019

de Moraes Pinto L, Ambrósio C, Goncalves Teiceira D, Cardoso Araújo K, Kfoury Júnior J, Morini Júnior J, Caroprezo Morini A, Grassi Risi R, Bolzani de Campos Ferreira G, dos Santos Martins D, Miglino M. Comportamento das células trofoblásticas gigantes na placenta de vacas Nelore (Bos Indicus - Linnaeus 1758). Rev Bras Reprod Anim 2008; 32:110-121.

Gorkiewicz G, Kienesberger S, Schober C, Scheicher S R, Gülly C, Zechner R, Zechner EL. A genomic island defines subspecies- specific virulence features of the hostadapted pathogen Campylobacter fetus subsp. venerealis. J Bacteriol 2010; 192:502-517. DOI: https://doi.org/10.1128/JB.00803-09

Hansen PJ. To be or not to be-determinants of embryonic survival following heat shock. Theriogenology 2007; 68:40-48. DOI: https:// doi.org/10.1016/j.theriogenology.2007.03.013

Hoffer M. Bovine Campylobacteriosis: A review. Can Vet J 1981; 22:327-330.

$\mathrm{Hu}$ L, Kopecko D. Interactions of Campylobacter with eukaryotic cells: gut luminal colonization and mucosal invasion mechanisms. In: Nachamkin I, Blaser M, editors. Campylobacter. Washington

DC: ASM Press; 2000. p.191-217. DOI: https://doi.org/10.1128/CMR.00055-07

Kaakoush NO, Castaño-Rodríguez N, Mitchell HM, Ming Man S. Global Epidemiology of Campylobacter Infection. Clin Microbiol Rev 2015; 28:687-720. DOI: https://doi.org/10.1128/CMR.00006-15

Takahashi H, Haneda S, Kayano M, Matsui M. Differences in progesterone concentrations and mRNA expressions of progesterone receptors in bovine endometrial tissue between the uterine horns ipsilateral and contralateral to the corpus luteum. J Vet Med Sc 2016; 78:613-618. DOI: https://doi.org/10.1292/jvms.15-0366

Terzolo H, Catena M. Género Campylobacter. In: Stanchi N, Martino PE, Enso EG, Reinoso H, Echeverría MG, Leardini NA, Copes JA, editors. Microbiología Veterinaria. Buenos Aires: Intermédica SAICI; 2010. p.274-80.

Ware D. Pathogenicity of Campylobacter fetus subsp. venerealis in causing infertility in cattle. Br Vet J 1980; 136:301-303. DOI: https://doi. org/10.1016/S0007-1935(17)32297-2 